\title{
Incivility in Controversies: The Influence of Presumed Media Influence and Perceived Media Hostility on the Antagonists in the German Conflict Over Aircraft Noise
}

Post, Senja

\begin{abstract}
Previous research suggests that the antagonists in conflicts are influenced by their perceptions of hostile media coverage and presumptions of media effects. Research so far has concentrated on presumed media influences on the general public. This study concentrates on presumed media influences on the conflicting parties. It tests how hostile media perceptions and presumptions of media effects on the conflicting parties affect the antagonists' acceptance of an uncivil and uncompromising style of public communication. In the context of the German controversy over aircraft noise, online surveys of 82 (47\%) opponents of aircraft noise and $48(33 \%)$ proponents of air traffic were conducted. Hostile media perceptions have no direct but an indirect effect on antagonists' intentions to communicate. They strengthen both parties' beliefs that the media make the protesters against aircraft noise more extreme. This, in turn, increases both parties' acceptance of incivility in the public dispute.
\end{abstract}

DOI: https://doi.org/10.1177/0093650215600491

Posted at the Zurich Open Repository and Archive, University of Zurich

ZORA URL: https://doi.org/10.5167/uzh-115263

Journal Article

Accepted Version

Originally published at:

Post, Senja (2017). Incivility in Controversies: The Influence of Presumed Media Influence and Perceived Media Hostility on the Antagonists in the German Conflict Over Aircraft Noise. Communication Research, 44(8):11491157.

DOI: https://doi.org/10.1177/0093650215600491 


\section{Incivility in controversies.}

The role of presumed media influence und perceived media hostility in the German controversy over aircraft-noise

Senja Post

Contact details:

Address: $\quad$ University of Zurich, IPMZ - Institute of Mass Communication and Media Research, Andreasstrasse 15, CH-8050 Zürich

Email: $\quad$ s.post@ipmz.uzh.ch

Author bio: Senja Post studied communication research in Dresden, Boston, and Mainz. In 2012, she completed her $\mathrm{PhD}$ with a thesis on “Scientists' and journalists' criteria of truth" in Mainz, Germany. From 2013 to 2015, she worked as a post-doc researcher at the University of Koblenz-Landau in a project investigating stakeholders' readiness to inform the public about scientific uncertainty in biotechnological research. Since 2015, she has worked as a senior research assistant at the University of Zurich. 


\title{
Incivility in controversies.
}

The influence of presumed media influence und perceived media hostility on the antagonists in the German conflict over aircraft noise

\begin{abstract}
:
Previous research suggests that the antagonists in conflicts are influenced by their perceptions of hostile media coverage and presumptions of media effects. Research so far has concentrated on presumed media influences on the general public. This study concentrates on presumed media influences on the conflicting parties. It tests how hostile media perceptions and presumptions of media effects on the conflicting parties affect the antagonists' acceptance of an uncivil and uncompromising style of public communication. In the context of the German controversy over aircraft noise, online surveys of 82 (47 percent) opponents of aircraft noise and 48 (33 percent) proponents of air traffic were conducted. Hostile media perceptions have no direct but an indirect effect on antagonists' intentions to communicate. They strengthen both parties' beliefs that the media make the protesters against aircraft noise more extreme. This, in turn, increases both parties' acceptance of incivility in the public dispute.
\end{abstract}

Key-Words: Media in Controversies - Influence of Presumed Media Influence - Hostile Media Perceptions - Incivility - Polarization Quantitative Survey 
The media frequently report on social or political conflicts such as the dispute over abortion, same-sex-marriage, the future of the welfare system, stem cell research, the deployment of armed forces, and many others. In private conflicts, the conflicting parties argue solely to persuade one another. In conflicts that are covered in the media (henceforth: "mediated conflicts"), they also seek to persuade the public and certain key actors by getting favorable news coverage (Kepplinger 2009, pp. 13). Covering a conflict, the media impose a specific dynamic on its development. For example, in order to gain supportive coverage, the conflicting parties have to adapt their messages to the "media logic" (Altheide \& Snow 1979), e.g. they have to present their information in a way that serves the news cycle and the needs of the media to reach a large audience (Strömbäck 2008).

The media influence the dynamics of conflicts also because they produce "reciprocal effects" on the subjects they cover (Lang \& Lang 1952, Kepplinger 2007; 2008). According to Kepplinger's model of reciprocal effects, the media influence the protagonists of news reports, i.e. individuals or members of a category of people that are covered in the media. As in mediated conflicts there are two types of protagonists - two conflicting parties pursuing opposing interests - the model of reciprocal effects has to be extended for the purpose of this study. In mediated conflicts, the protagonists of news reports are the antagonists. Kepplinger also distinguishes between protagonists and "bystanders" (Kepplinger 2007, p. 4). Whereas the protagonists, or, in the case of con- 
flicts the antagonists, belong to groups of people whose activities are frequently covered in the media, bystanders are viewers, readers or listeners who are not actively involved in the conflict - though they may personally lean toward one or the other side.

The following is a study of the reciprocal effects of news coverage on the antagonists in conflicts. Pursuing their goals, the antagonists react to coverage about themselves or the disputes they are involved in in various ways. Among others, they probably derive communication strategies from previous coverage, striving to improve a bad image, maintain a good one and to push forth their interests (De Nooy \& Kleinnijnhuis 2013; Kepplinger 2007, pp. 8). They likely react to previous coverage based on their perceptions of the news and their anticipations of media effects. Previous research has indicated that the antagonists in conflicts perceive media coverage to be hostile to their respective positions. It has further indicated that hostile media perceptions, along with presumptions that media coverage is influential (Tsfati \& Cohen 2005; Tsfati 2007), can lead to "increased polarization of extreme groups" (Gunther 2008).

Research so far has mostly dealt with actors' presumptions of media effects on the general public and their consequent behaviors or behavioral intentions. However, in concrete mediated conflicts it seems relevant to study antagonists' presumptions of media effects on the two opposing sides. This is the objective of the present study. It seeks to investigate how both sides of a con- 
crete conflict - the opponents of aircraft noise and the proponents of air traffic in the German controversy over aircraft noise - intend to communicate in public. Doing so, it draws on concepts such as hostile media perceptions (Vallone, Rosse \& Lepper 1985) and the influence of presumed media influence (Gunther \& Storey 2003). The general assumption is that due to hostile media perceptions and presumptions that the media make both sides of the conflict more extreme, the conflicting parties become more uncompromising and aggressive in tone.

\section{Concepts}

\section{Hostile Media Perceptions}

Partisans tend to perceive media coverage as hostile to their points of view even when coverage is evenhanded. Vallone, Rosse \& Lepper (1985) exposed American pro-Arab and pro-Isreali students to US TV news reports on the 1982 Beirut massacre when Christian militias killed Palestinian and Lebanese refugees. Although both groups watched identical news items they perceived them as hostile toward their own points of view. Pro-Arab students perceived the news reports to be biased against Arabs whereas pro-Isreali students perceived them to be biased against Israelis. So-called hostile media perceptions have been found among groups or partisans with regard to general political ideology (Barnidge \& Rojas 2014; Coe, Tewksbury, Bon, Drogos, Porter, Yahn \& Zhang 2008; Rojas 2010) and in specific contexts such as election campaigns (Huge \& Glynn 2010), the Gaza settlements (Tsfati \& Cohen, 
2005), Arab minorities in Israel (Tsfati 2007) controversies over abortion (Hartman \& Tanis, 2013), stem-cell research (Hoet al., 2011) or climate change (Feldman, Myers, Hmielowski, \& Leiserowitz, 2014). Much research has been dedicated to explain hostile media perceptions. Important drivers are, among others, the degree of involvement in an issue (Chois, Yang \& Chang 2009; Matthes 2013), and the degree of group identification (Hartman \& Tanis 2013; Reid 2012; Stroud, Muddiman \& Lee 2014). Antagonists in mediated conflicts are partisans with opposing views. They can be assumed to be highly involved in the controversial issues at stake and to identify strongly with their respective interest group when perceiving media coverage of the controversial issue. One can thus expect that the antagonists on either side of a mediated conflict will perceive coverage as unfavorable to their own and favorable to their adversaries' position (Hypothesis 1).

\section{Presumed Media Influence}

Media coverage can be influential by making people presume it influences other people and change their attitudes or behaviors as a consequence (Davison 1983). For instance, Gunther \& Storey (2003) demonstrated such effects of a radio campaign broadcast on the general radio program but directed primarily at health workers in Nepal to improve their interactions with patients. The campaign was successful not so much because it influenced health workers as because the general population presumed it did. Their presumptions, in turn, made the general population change their attitudes and behaviors toward 
the health workers, improving interactions overall. The influence of presumed media influence is a component of so-called third-person effects. Especially when confronted with negative or normatively undesirable media contents, people anticipate much greater effects on other people than on themselves causing various behavioral or attitudinal consequences (Davison 1983; Perloff 1999).

While earlier studies focused primarily on the origins and consequences of the discrepancies between presumed effects on the self and on others more recent works have concentrated on the attitudinal or behavioral consequences of presumed media influences on other people (cf. Tal-Or, Tsfati \& Gunther 2009). Tal-Or et al. (2009, pp. 105) distinguish three types of consequences - prevention, coordination, and normative influence. Prevention effects refer to subjects' attempts to stop or limit the distribution of allegedly harmful, influential media content, e.g. by supporting censorship (e.g. Bernhard \& Dohle 2014; Cohen \& Weimann 2008; Dohle \& Bernhard 2014; Perloff 1999, pp. 367). Coordination effects refer to subjects' efforts to take into account others' presumed reactions to media coverage when developing strategies to achieve their goals. An example of this is strategic voting due to presumed media influences on other voters (Cohen \& Tsfati 2009). Normative influence refers to subjects' compliance with or defiance of social norms they presume to emerge or reinforce as a consequence of media coverage. E.g., members of the Arab minority in Israel who presumed media coverage to create a negative image of 
their community among the Jewish-Israeli majority have been found to withdraw from social life - apparently complying with their perceptions of the majority's normative beliefs (Tsfati 2007). Another example is found in adolescents who adopt their smoking (Gunther, Bolt, Borzekowski, Liebhart, \& Dillard, 2006; Paek, 2009) or sexual behavioral intentions (Chia, 2006) to how they believe specific media or campaign contents influence the social norms within their peer group. By contrast, the Jewish settlers in Gaza defied their presumptions of the media creating a negative image of the Gaza settlements by justifying violent actions (Tsfati \& Cohen 2005). Another example of defiance can be seen in partisans' efforts to "correct" allegedly negative media effects by political online or offline activism (e.g. Barnidge \& Rojas 2014; Rojas 2010).

In addition to these effects on general audiences presumptions of media effects influence potential news sources' public relations efforts. E.g., the more scientists (Tsfati, Cohen \& Gunther 2011), or politicians (Cohen, Tsfati \& Sheafer 2008; Amann, Dohle \& Raß 2012) assume that news coverage of themselves is conducive to their careers the more they intensify their public relations efforts. Similary, the more politicians assume their communication via social and online media to have beneficial effects the more they intensify their use of such channels of communication (e.g. Bernhard \& Dohle 2015b).

This study will explore the consequences of antagonists' hostile media perceptions and presumed media effects on their own side and their opponents. Be- 
fore concrete hypotheses are presented, a literature review of the potential effects of hostile media perceptions and presumed media influences in mediated conflicts will be given.

\section{Hostile Media Effects on Antagonists' Styles of Communication}

In mediated conflicts, perceptions that media coverage is hostile affect antagonists' readiness to engage in public discourse. Minority groups have been found to feel alienated from society as a consequence of perceptions of negative media coverage (Tsfati 2007). In conflicts where the disputing parties are more balanced in size and influence, antagonists have been found to intensify their discursive activities by engaging in so-called "corrective actions" (Rojas 2010). They talk to politicians more frequently, sign petitions, try to convince people through online communications, organize or join demonstrations etc. in order to counter-balance the allegedly hostile media coverage (Barnidge \& Rojas 2014; Feldman et al. 2015; Ho et al. 2011; Hwang et al, 2008).

While some researchers (Ho et al. 2011) have wondered whether, due to their mobilizing effects, hostile media perceptions are conducive to democratic participation there are hints that they are not. Ho et al. (2011) show that hostile media perceptions do not mobilize the public at large but the publics of controversial issues. For several controversial issues Hwang et al. (2008) show that an important driving force between hostile media perceptions and discursive activities is "media indignation" - an emotional construct composed of contemptuousness, anger, disgust and resentfulness (p. 83). The authors show 
that hostile media perceptions enhance feelings of media indignation, which in turn increase willingness to engage in discursive activities. In other words, hostile media perceptions mobilize subjects to political or discursive actions by way of making them feel negatively aroused.

It seems plausible that feelings of indignation resulting from hostile media perceptions do not only foster subjects' readiness to take part in political or discursive activities but also influence their styles of communication. Tsfati \& Cohen (2005, p. 804) have shown that in the violent conflict of the Gaza settlements, hostile media perceptions increased the settlers' justifications of aggressions, i.e. the use of violence. Against this background, one can expect that in non-violent conflicts, hostile media perceptions strengthen subjects' preference for a style of communication that is verbally aggressive, and, "in which individuals rather than their ideas or positions on issues are attacked" (Eveland, Morey and Hutchens 2011, p. 1094). Such a style of communication has been termed "uncivil" in political communication (Hmielowski, Hutchens \& Cicchirillo 2014; Wolf, Strachan \& Shea 2012). It denotes a lack of politeness whose social function is "to promote social harmony among potentially aggressive parties" (Wolf, Strachan \& Shea 2012). Based on previous research one can assume that hostile media perceptions cause antagonists in mediated conflicts to avoid compromise and give up a functional relationship. The present study tests the assumption that in a non-violent conflict, hostile media perceptions will increase antagonists' acceptance of an uncompromising rhet- 
oric (Hypothesis 2a) and their acceptance of an uncivil style of communication (Hypothesis 2b).

\section{Hostile Media Effects on Antagonists' Presumed Media Influence}

Several studies suggest that hostile media perceptions shape presumptions of media effects. I.e., the mobilizing effects of hostile media perceptions on antagonists' political or discursive participation are mediated by their presumptions that media coverage is influential (Barnidge \& Rojas 2014; cf. Perloff 1999, pp. 366; Tsfati 2007; Tsfati \& Cohen 2005). Most of these studies have measured presumptions of media effects on "others", "people" or "the public" in general (Barnidge \& Rojas 2014; Bernhard \& Dohle 2013; Cohen \& Tsfati 2005; Rojas 2010). A few studies, however, have looked at presumed media effects on the conflicting parties - i.e. on antagonists' in- and / or out-group. For instance, Tsfati (2007) showed that hostile media perceptions made Arabs in Israel believe that Jewish Israelis (outgroup) had a negative image of them predicting, eventually, their social alienation. Based on social identity theory, postulating that people in conflicts conceptualize their selves in terms of their membership in social groups, Hoffner \& Rehkoff (2011) measured partisans' presumptions of media influences on Republicans and Democrats in the 2004 US presidential election campaign. With a similar reasoning Oliver et al. (2008) showed that partisans in conflicts tend to presume that media coverage reinforces the antagonizing parties' predispositions. In their study of the 2008 US presidential election campaign, Wolf et al. (2012) presented hints as to 
how hostile media perceptions may influence antagonists' impressions of their in- and outgroup's reactions to media coverage. They found that partisans blame opposing media coverage for the rise of an uncivil tone in the public political dispute. Partisans presume, in other words, that opposing media coverage has made the political parties adopt a more confrontational, irreconcilable tone of negotiation. A similar pattern seems plausible in concrete mediated conflicts. One can expect that hostile media perceptions make the antagonists presume that media coverage makes the conflict more heated. Specifically, this study tests the assumptions that hostile media perceptions make the antagonists of a conflict presume that the media make the conflicting parties more extreme (Hypothesis 3). It seems particularly relevant to clarify whether hostile media perceptions influence the antagonists' presumptions of media effects on their own side (ingroup) in the same way they presume it influences the other side (outgroup) (Research question 1).

\section{Influence of Presumed Media Influence on Antagonists' Communication Styles}

Presumptions of media influences on the conflicting parties can have attitudinal or behavioral effects on the antagonists in conflicts. E.g. Hoffner \& Rehkoff (2011) showed that Democrats and Republicans who presumed the media to influence their respective outgroup supported censorship of allegedly unfair or misleading media coverage. Wolf et al. (2012) have presented hints that partisans presuming the media to heat up a controversial dispute are reluc- 
tant to compromise. In their study of US-American voters, they show that strong partisans who blame opposing media coverage for having heated up the political discourse prefer uncompromising candidates, i.e. candidates who "stand firm on principle" (Wolf et al. 2012, 1689). In other words, strong partisans who presume that opposing media coverage has made the political parties more confrontational reject compromising candidates. One might expect that a similar pattern holds for the antagonists in mediated conflicts. Specifically, one might assume that presumptions that hostile media coverage has made the participants of the dispute more extreme lead them to accept an uncompromising (Hypothesis 4a) and uncivil (Hypothesis 4b) style of communication. In this context, it seems relevant to clarify whether presumptions of media effects on the participants' own (in-group) and the opposing side (outgroup) have the same effects on their acceptance of an uncivil and uncompromising style of communication (Research Question 2).

Hypotheses 2 to 4 of this study can be summarized in a conceptual model (Figure 1) in which hostile media perceptions lead the antagonists to accrept a more aggressive and uncompromising style of communication (Hypotheses 2a and $b$ ). In addition, hostile media perceptions are expected to have a mediated influence on the antagonists' styles of communication: Hostile media perceptions make the antagonists believe that media coverage makes the conflicting parties more extreme (Hypothesis 3). This assumption, in turn increases their inclination to adopt a more aggressive and uncompromising style of commu- 
nication (Hypotheses 4a and b). Before these hypotheses are tested in a mediated effects model, the context of this study, i.e. the German conflict over aircraft noise will be given.

[insert figure 1 about here]

\section{The Controversy over Aircraft Noise in Germany}

From 1975 till 2014, the number of aircraft movements in Germany rose from .74 to almost 3 millions (Deutsche Flugsicherung [DFS, German flight control] 2013). This development went along with an increasingly heated conflict between citizens suffering from rising levels of aircraft noise in the partly very densely populated areas around the German airports and the air traffic industry, i.e. airports and airlines. While the air traffic industry argues that expansions of air traffic volume have beneficial consequences on the regional and national economies - attracting businesses, creating jobs, improving infrastructure, and maintaining competitiveness for several business branches - the protesters argue that air traffic noise has detrimental effects on the environment, citizens' health, real estate value and the quality of life in general, decreasing economic productivity overall.

As, with a passenger volume of about 58 millions in 2013, the airport of Frankfurt is the biggest airport in Germany and because it is situated in the densely populated Rhine-Main area, the conflict has been most heated there. When in 2011, Fraport opened a new runway, existing citizen action groups mobilized the residents to protest and many new action groups formed. Since 
the new runway was opened in 2011 , the protesters have demonstrated at Frankfurt Airport every Monday, attracting the attention of regional and national media. Not only in Frankfurt but also in other regions all over the country have citizens been demonstrating against aircraft noise. In Munich, about 80 action groups and NGOs are demonstrating against the expansion of the second largest German airport. In Cologne, action groups demonstrate against night flights and in Berlin, where a new international airport is still being built, action groups demonstrate for flying routes around the city, for a system imposing fees on loud aircrafts and against establishing an international hub at the new airport. There are many more citizen action groups not only in the areas surrounding smaller international airports like Hamburg, Dusseldorf, Stuttgart or Nuremburg, but also in the areas surrounding regional airports like Dortmund or Bremen. As the protests have intensified in the last couple of years and protests against aircraft noise have spread around the country, it has attracted increasing media attention.

The citizen action groups are organized in the Federal Union against Aircraft Noise, a registered lobby-group (BFV, Bundesvereinigung gegen Fluglärm). Apart from fighting expansions of airports, they demand a nationwide ban on flights between $10 \mathrm{pm}$ and $6 \mathrm{am}$. Along with the development of air traffic volume, night flight is one of the biggest issues in the conflict. A ban on flights between $10 \mathrm{pm}$ and 6 am only exists at the regional airports of Dortmund and Memmingen. In Frankfurt, flights are banned between $11 \mathrm{pm}$ and 5 
am, in Munich, Dusseldorf, Stuttgart and most other cities airports are closed between 0 and 5 am. In Leipzig, freight carriers may fly after midnight. In Cologne, Nuremberg, Hanover and other cities, there are no flight restrictions at night at all. The air traffic industry along with business branches depending on regular flights like courier and postal services or freight forwarders, argue heavily against a ban on flights at night for economic reasons.

\section{Method}

\section{Survey}

Online-surveys of the antagonists in the conflict over aircraft noise were conducted with the speakers of citizen action groups against aircraft noise on the one hand and speakers of companies or trade associations from the air traffic industry and other directly dependent industry branches on the other hand. The goal was to interview individuals who were in charge of representing their group or organization in the public discourse - those, in other words, who actively shape the tone of the debate in the interest of their group or organization. Especially on the part of the citizen action groups, the selection of official speakers may come along with a disadvantage. Among the opponents, not only the official speakers raise their voice in public but many others, e.g. by attending public protests against aircraft noise that attract media attention. Nevertheless, compared with the official speakers, their discursive activities are rather sporadic and, taken individually, probably less visible than the discursive actions of the official speakers. Also, by contacting the speakers, of 
the citizen action groups it was made sure that comparable groups on both sides were targeted. Both among the opponents and the proponents, the official speakers, or, if existent, the public experts of aircraft noise were contacted - i. e. those on both sides who handle their press and public relations, who serve as primary and official sources for journalists as well as other people making inquiries, and who can shape the public discourse most effectively in the interest of their respective group.

The speakers of the citizen action groups were identified on the website of the BVF, which lists the speakers of all member citizen action groups against air craft noise all across Germany. This list was complemented by a list of citizen action groups provided by the German Aircraft Noise Service (DFLD, Deutscher Fluglärmdienst). It is a member of the BFV and provides measurements of aircraft noise as a service to citizens and communities. On its webpage, it provides a list with links to all German citizen action groups against aircraft noise running a homepage. The lists of the BVF and the DFLD overlapped in large parts. All in all, 177 German citizen action groups against aircraft noise were identified. From each one, the press speaker was added to the list of the survey's addressees.

The representatives of the air traffic industry were identified in several steps. First, the relevant trade associations were identified in the so-called "lobbylist" of the German parliament. This list is based on the self-registration of German lobby and interest groups. Although registration is voluntary, most 
German interest groups register because it is generally assumed that it enhances the chance to be invited to public hearings in the German Parliament (Deutsches Institut für Public Affairs [Geman Institute for Public Affairs] 2006). In this list, eight industry associations relevant for the air traffic industry were identified and their speakers were compiled in a list of addressees of the survey. In the next step, all the associations' members involved in the development of air traffic in Germany were added to the list of addressees, i.e. members running air traffic (airlines), providing infrastructure for it (airports) or supporting it politically (e.g. regional chambers of commerce and industry; trade associations). Members of the aircraft industry, i.e. companies or associations involved in the engineering and construction of aircrafts were not added to the list of addressees. In the next step, all addressees' websites were examined thoroughly to look for allies in the conflict against aircraft noise. Such allies were often found in position papers or statements published on the issue of night flight or expansions of air traffic on companies' or associations' websites. All such partners who explicitly supported night flight or the expansion of air traffic in Germany were added to the list of addressees of the survey. Through this process, 149 organizations were identified, among them airports, airlines, regional chambers of commerce and industry, regional and national trade associations, postal and courier services as well as freight forwarding associations and companies. From each organization, the official spokesperson for aircraft noise was identified. If such a person did not exist, the general spokesperson was identified. 
Fieldwork lasted from July $1^{\text {st }}$ till August $15^{\text {th }}, 2014$. The addressees received a pre-notice by email to announce the survey and introduce the topic "media coverage of aircraft noise". They then received three emails with invitations to participate and a link to the online-survey in an interval of ten days each. The link could only be used once to fill out the survey. This was to ascertain that the link could be passed along to the targeted person within an organization but could not be used to fill out the questionnaire several times. Participants from each side of the conflict were highly interested in the study. Many sent emails to confirm their participation or to provide additional information. Some called back by phone. There was no hint that individuals other than those targeted filled out the questionnaire. In some cases, the speakers obviously conferred with the board of their respective group or organization as became clear from their feedback. This indicates a highly politicized situation in which the antagonizing groups sought consultation among their colleagues or fellow members. Thus, it can reasonably be assumed that in most of the probably rare cases in which the questionnaire was forwarded to a person other than the one targeted, that person filled out the questionnaire with the intention to represent his or her group's or organization's interests.

Other addressees were hesitant to participate. Some spokespersons of companies were difficult to reach. Some citizen action groups from the Rhine-Main area were highly suspicious. Several citizen action groups of the city of Mainz near Frankfurt Airport gave a coordinated reply and justified their collective 
refusal with their fear of being sounded out by the air traffic industry. Apparently, they had experienced this before in another study. A participant from another town in the Rhine-Main area wrote: "For those, who have spent years to deal with the problem of aircraft noise (...) studies by 'unknown' persons are highly suspicious. They had to experience too often how, in the name of science but with most dubious methods, they were played hard and loose with."

Despite these discouraging remarks the response rates were surprisingly high. Of the 149 organizations proposing the expansion of air traffic four turned out ineligible because they were not concerned with air traffic but otherwise with making Germany competitive in logistics businesses. Of the remaining 145 organizations, 48 (33 percent) participated. Most of the participants (50 percent) are representatives of the air traffic industry (i.e. working at airports or airlines), some work in trade associations ( 8 percent), consulting ( 8 percent), freight forwarding or courier services ( 6 percent) or chambers of commerce ( 6 percent). On average, the proponents are 48,74 years old. Most of them have a college degree ( 85 percent). 71 percent of the proponents of air traffic are male, 19 percent are female. The rest did not give any information about their gender. Of the 177 spokespersons of action groups against aircraft noise one turned out ineligible because the action group was no longer active. Of the remaining 176 action groups, 82 (47 percent) participated in the survey. Turnout differed across regions. Of all the action groups against aircraft noise in 
Germany, most are located around Frankfurt airport. Second comes the area around Munich, then Cologne / Bonn, Berlin and Halle / Leipzig. In the final sample, the citizen action groups around Frankfurt airport are underrepresented (Table 1) as could be expected from participants' feedback (see above). Accordingly, the response rate in the Frankfurt area was lower than in other areas (24 percent). In Munich, it was 54 percent, in Cologne / Bonn it was 47 percent, in Berlin 54 percent, in Halle / Leipzig 60 percent and in all other regions taken together, the response rate was 71 percent. The potential consequences of the differing response rates will be addressed in the discussion of this study. With an average of 60.41 years of age, the speakers of the citizen action groups are quite old. 73 percent are male, 21 percent are female. The rest $(6 \%)$ did not give any information about their gender. They are also quite highly educated. Two thirds of them (67\%) have a college degree, 15 percent have stopped their education with a high school diploma. Only 15 percent have an educational level below this. The rest (4\%) did not answer this question.

(Insert table 1 about here)

\section{Measures}

Dependent variables. Respondents' acceptance of an uncompromising rhetoric was measured in one item asking them to give their level of agreement with the statement that, "in a public controversy, one must express one's claims as uncompromisingly as possible in public." The scale ranged from 1 
("do not agree at all") to 7 ("totally agree"). The action groups against aircraft noise accept an uncompromising rhetoric significantly more $(\bar{x}=4.96, \mathrm{SD}=$ 1.674) than the proponents of air traffic $(\bar{x}=3.19, \mathrm{SD}=1.424 ; \mathrm{T}=7.637, \mathrm{df}=$ $128, \mathrm{p}<.001)$. Respondents' inclination to accept an uncivil tone in the debate was measured in a six-item measure asking them for their degree of acceptance of a concrete fictitious case. It was constructed in two versions so that respondents from both groups were asked about the behavior of a fictitious person in their in-group. The case read: "Suppose politicians, action groups against aircraft noise and representatives of the air traffic industry discuss the economic and health-related consequences of air traffic in a public event. Suddenly, an attendant jumps up and shouts: 'You protesters against aircraft noise / people from the air traffic industry - you are nothing but ignorant liers!' Below you find a few comments on this reaction. To what degree do they reflect your own opinion?" On a scale from 1 (“does not reflect my opinion at all") to 7 (“totally reflects my opinion"), participants were asked to rate the degree to which they thought the reaction was justified or understandable in six items ("I think his reaction is totally justified", "I can understand his reaction", "I think he is right", "I might react in the same way", and, reverse coded, "I think his reaction is totally unacceptable", "I think his reaction is totally incomprehensible"). Summed up, the six items indicate respondents' acceptance of incivility in the conflict over aircraft noise in an index ranging from 6 to 42. For the opponents of aircraft noise, this scale has a high internal consistency with with Cronbach's $\alpha=.892$. For the proponents of air traffic, 
internal consistency is lower but still acceptable with Cronbach's $\alpha=.685$. The opponents of aircraft noise accept incivility more $(\bar{x}=28.20$, SD $=$ $10.133)$ than the supporters of air traffic $(\bar{x}=16.63, \mathrm{SD}=6.823 ; \mathrm{T}=7.637, \mathrm{df}$ $=120.823, \mathrm{p}<.001)$.

Independent variable. As in many previous survey studies on the effects of hostile media perceptions (Barnidge \& Rojas 2014; Feldman et al. 2015; Hwang et al. 2008; Rojas 2010; Tsfati 2007), respondents were asked to evaluate general media coverage on the respective issue in question. In the present case, they were asked to estimate the degree to which the media report in favor of a reduction or of an expansion of air traffic in Germany on a scale ranging from 1 ("definitively in favor of reduction") to 7 ("definitively in favor of expansion"). The mean-comparisons will be given below.

Mediating variables. Respondents' presumptions of media coverage influencing their own and the opposing side were measured in two items. One asked respondents to estimate the degree to which media coverage caused the opponents of aircraft noise to become more moderate or extreme. The other asked respondents to estimate the degree to which media coverage caused the proponents of air traffic to become more moderate or extreme. Participants gave their estimates on 7-point semantic differentials from 1 "more moderate" to 7 "more extreme". Their estimates were recoded so as to indicate the degrees to which respondents believe their own party and their counter-party becomes more moderate or extreme as a consequence of media coverage. The 
opponents of aircraft noise think more $(\bar{x}=4.68, \mathrm{SD}=1.152)$ than the proponents of air traffic $(\bar{x}=3.74, \mathrm{SD}=1.002 ; \mathrm{T}=4.442, \mathrm{df}=118, \mathrm{p}<.001)$ that the media has made their own side more extreme. The supporters of air traffic think more $(\bar{x}=5.43, \mathrm{SD}=1.193)$ than the opponents of aircraft noise $(\bar{x}=$ 4.84, $\mathrm{SD}=1.392 ; \mathrm{T}=-2.412, \mathrm{df}=127, \mathrm{p}<.05)$ that the media has made the opposing side more extreme.

Controls. Apart from hostile media perceptions and presumed media influences, the effects of four control variables on the antagonists' acceptance of an uncompromising rhetoric and uncivil style of communication were tested. First, their perceived ability to make their position heard in the media ("media self-efficacy") was tested. It was measured in one item ("We can make our views heard in the media") on a scale from 1 ("do not agree at all") to 7 ("totally agree"). The opponents of aircraft noise $(\bar{x}=3.85, \mathrm{SD}=1.754)$ and the proponents of air traffic $(\bar{x}=3.94, \mathrm{SD}=1.420 ; \mathrm{T}=-.296, \mathrm{df}=112.702$, n.s. $)$ are similarly self-efficient in terms of their access to the media. Second, the influence of the antagonists' own position on the issues of air traffic development was tested. It was measured in one item ("To what degree should air traffic in Germany be reduced or expanded?") on a scale from 1 ("should be reduced considerably") to 7 ("should be expanded considerably"). As can be expected, the opponents of aircraft noise are largely in favor of a reduction of air traffic $(\bar{x}=1.95, \mathrm{SD}=1.115)$ while the proponents of air traffic are largely in favor of an expansion $(\bar{x}=5.20, \mathrm{SD}=.919 ; \mathrm{T}=-17.444, \mathrm{df}=106.541, \mathrm{p}<$ 
.001). Third, the influence of antagonists' perceptions of politicians' views were tested. They were measured in one item on a scale from 1 ("should be reduced considerably") to 7 ("should be expanded considerably"). The opponents of aircraft noise perceive politicians to be largely in favor of an expansion of air traffic $(\bar{x}=5.57, \mathrm{SD}=1.111)$, while the proponents of air traffic perceive politicians to be in favor of neither reducing nor expanding it $(\bar{x}=$ $3.98, \mathrm{SD}=1.113 ; \mathrm{T}=7.817, \mathrm{df}=127, \mathrm{p}<001)$. Fourth, the antagonists' frequency of media use was measured in four items asking them about the frequency of their use of newspapers, weekly magazines, TV and radio to receive information about the conflict over aircraft noise. It was measured on a scale from 1 ("never") to 7 ("very frequently"). Summed up in an index, the four items indicate respondents' frequency of media use on the issue of aircraft noise with values ranging from 4 ("never") to 28 ("very frequently"). Cronbach's $\alpha$ scores .726 among the opponents of aircraft noise and .887 among the proponents of air traffic. The opponents of aircraft noise $(\bar{x}=$ $19.81, \mathrm{SD}=5.713)$ and the proponents of air traffic $(\bar{x}=20.39, \mathrm{SD}=6.108 ; \mathrm{T}$ $=-.529, \mathrm{df}=116, \mathrm{n} . \mathrm{s}$.) use the media to very similar degrees.

To test whether the antagonists perceive the media to be hostile toward their points of view, mean comparisons were conducted. To test the influence of perceived media hostility on the antagonists' acceptance of an uncompromising and uncivil style of communication multiple mediator analyses were conducted with the SPSS macro PROCESS (Hayes 2013). It will be used to esti- 
mate the direct influence of perceived media hostility on the antagonists' acceptance of an uncivil and uncompromising style of communication as well as its indirect influence mediated through their presumptions of media effects on their own and on their counter party (Preacher \& Hayes 2008; Field 2013).

\section{Results}

\section{Hostile Media Perceptions}

The antagonists in the conflict over aircraft noise perceive media coverage to largely favor their opponents. On a scale from "the media report largely in favor of a reduction" (1) to "the media report largely in favor an expansion of air traffic" (7), the opponents of aircraft noise think that the media favor an expansion $(\bar{x}=5.24, \mathrm{SD}=1.238)$, while the proponents think they favor a reduction $(\bar{x}=2.42, \mathrm{SD}=964)$. The difference is highly significant $(\mathrm{T}=$ 14.440, $\mathrm{df}=17.544, \mathrm{p}=.000)$ and thus confirms hypothesis 1 .

For the following analysis, the values of the scale were recoded in order to indicate the degree of perceived hostility - i.e. for the opponents of aircraft noise, perceived reporting in favor of a reduction of air traffic was recoded as perceived friendliness (1), and perceived reporting in favor of an expansion was recoded as perceived hostility (7). For the proponents of air traffic, perceived reporting in favor of an expansion of air traffic was recoded as perceived friendliness (1), and perceived reporting in favor of a reduction was recoded as perceived hostility (7). The two parties perceive media coverage to favor their counter-party's views to a very similar degree (opponents of air- 
craft noise: $\bar{x}=5.25, \mathrm{SD}=1.238$; proponents of air traffic: $\bar{x}=5.58, \mathrm{SD}=$ $.964 ; \mathrm{T}=-1.597, \mathrm{df}=126 ; \mathrm{n} . \mathrm{s}$.$) .$

\section{Direct Influences of Hostile Media Perceptions on the Antagonists' Ac- ceptance of Incivility and an Uncompromising Rhetoric}

Mediation analyses using bootstrapping procedure (Hayes 2013) were calculated, predicting the antagonists' acceptance of an uncivil and uncompromising style of communication. For both the opponents of aircraft noise and the proponents of air traffic, two mediation models with two mediators each were calculated - one to explain acceptance of incivility and one to explain acceptance of an uncompromising rhetoric. All mediation analyses were conducted with 10.000 bootstrapping samples and bias-corrected estimates. The antagonists' perceptions of hostile media were entered as independent variables and their presumptions that the media make the two sides of the conflict more extreme as mediating variables. The control variables mentioned above were entered as covariates. The models yield significant explanations for both the opponents' and proponents' acceptance of incivility (opponents: $\mathrm{R}^{2}=.367$; $\mathrm{p}<.01$; proponents: $\left.\mathrm{R}^{2}=.348 ; \mathrm{p}<.06\right)$. ${ }^{\mathrm{i}}$ In the case of the opponents of aircraft noise, they also yield a significant explanation for their acceptance of an uncompromising style of communication $\left(\mathrm{R}^{2}=.241 ; \mathrm{p}<.05\right)$.

Due to non-response, the number of cases was reduced for all the models. Among the 82 opponents, there were 23 missing cases for the model explaining respondents' acceptance of incivility, and 21 missing cases for the model 
explaining their acceptance of an uncompromising rhetoric. Among the 48 proponents, there were 11 missing cases for the model explaining respondents' acceptance of incivility, and 10 missing cases for the model explaining their acceptance of an uncompromising rhetoric. The reduction of cases is largely due to respondents' refusal to estimate their media use, particularly their use of weeklies (10 missing cases among the opponents, 1 among the proponents) and their refusal to rate the degree to which the media make their own party more extreme (5 missing cases among each the proponents and opponents). Small amounts of missing data exist for other variables in the model increasing the number of non-responses further. In order to check for systematic differences between respondents and non-respondents, participants were divided into two groups - those who answered all relevant questions and were included in the analyses and those who did not answer all the relevant questions and were excluded from the analyses. Mean comparisons between respondents and non-respondents for all main variables and covariates in the models reveal no significant differences except in one case. ${ }^{i i}$ Among proponents of air traffic, respondents tend to accept an uncompromising rhetoric $(\bar{x}=3.43, \mathrm{SD}=1.37)$ more than non-respondents $(\bar{x}=2.36, \mathrm{SD}=1.36, \mathrm{~T}=-2.28, \mathrm{df}=46, \mathrm{p}=.027)$. Yet this difference does not have any consequences for the following analysis here, because, as was shown above, the model explaining proponents' acceptance of an uncompromising rhetoric is far from reaching significance $(\mathrm{p}=$ .745). What is more, the mean comparisons between respondents and nonrespondents suggest that it would not reach significance if the non-respondents 
were included because they seem to be somewhat more reluctant than the respondents to accept an uncompromising rhetoric. It seems plausible that those who are generally more reluctant to embrace an uncompromising rhetoric are also less likely to do so as a response to hostile media perceptions or presumed media influences.

All the models reveal that there is no direct relationship between hostile media perceptions and the antagonists' acceptance of an aggressive style of communication or an uncompromising rhetoric (table 2). This clearly disconfirms hypotheses $2 \mathrm{a}$ and $\mathrm{b}$.

[table 2 about here]

\section{Influences of Hostile Media Perceptions on Presumptions that the Media Make the Conflicting Parties More Extreme}

The antagonists' presumptions of media effects on the conflicting parties are partly predicted by their perceptions of hostile media. Significant explanations are obtained for the antagonists' presumptions of media influences on their adversaries' claims and in the case of the opponents of aircraft noise, also for their presumptions of media influences on their own side's claims (table 3). The more the opponents of aircraft noise think that media coverage is hostile toward their position, the more they are convinced that media coverage causes both sides of the conflict to make increasingly extreme claims. The more the proponents of air traffic think that media coverage is hostile towards their position, the more they are convinced that media coverage causes their coun- 
ter-party to make increasingly extreme claims. Their perceptions of hostile media coverage is not associated with their presumptions of media effects on their own party. With one exception, this supports hypothesis 3, which purported that hostile media perceptions positively relate to the antagonists' presumptions that both sides of the conflict become more extreme.

[table 3 about here]

\section{Influences of Presumed Media Effects on Antagonists' Acceptance of In- civility and an Uncompromising Rhetoric}

Antagonists' acceptance of incivility and, in the case of the opponents of aircraft noise, their acceptance of an uncompromising rhetoric, is associated with their presumptions of media influences on their own party or their counterparty. But there are striking differences (table 2). The more the opponents of aircraft noise presume that media coverage has made their own side more extreme the more they accept an uncompromising rhetoric and uncivil style of communication. The more the proponents of air traffic presume that media coverage has made their adversaries more extreme the more they accept an uncivil style of communication. In other words, the more both the opponents of aircraft noise and the proponents of air traffic believe that media coverage has made the opponents of aircraft noise more extreme the more they accept an uncivil style of communication. These results partly confirm hypotheses $4 \mathrm{a}$ and $b$. 


\section{Indirect Effects of Hostile Media Perceptions on Acceptance of Incivility and an Uncompromising Rhetoric}

As has become clear, hostile media perceptions are not, as expected, directly associated with the antagonists' acceptance of an uncompromising rhetoric or incivil style of communication. The mediation analyses show that there is an indirect relationship between hostile media perceptions and antagonists' acceptance of incivility. In the case of the opponents of aircraft noise, there is also an indirect association between hostile media perceptions and their acceptance of an uncompromising rhetoric. The bootstrapping procedure provides estimates of $95 \%$ confidence intervals for whether there is an indirect effect of hostile media perceptions on antagonists' acceptance of incivility and an uncompromising rhetoric. An estimate for an indirect effect is considered significant if zero is not included in the $95 \%$ confidence interval. Hostile media perceptions have a mediated effect on antagonists' acceptance of incivility and, in the case of the opponents of aircraft noise, on their acceptance of an uncompromising rhetoric. The analyses show the following chains of relationships: The more the opponents of aircraft noise perceive the media to be hostile toward their point of view the more they are convinced that media coverage makes their own side of the conflict more extreme. The more they are convinced of this, the more they accept incivility and an uncompromising style of public communication. The mediated effects of hostile media perception on their acceptance of incivility and an uncompromising rhetoric are significant 
although in both cases, the closeness of the confidence intervals to zero indicate that the indirect effects are relatively small (acceptance of incivility: $B=$ $.8311 ; S E=.5162 ; 95 \%$ confidence interval $[.0756 ; 2.2569]$; acceptance of an uncompromising rhetoric: $B=.1380 ; S E=.0882 ; 95 \%$ confidence interval $[.0185 ; .3869])$. The more the proponents of air traffic perceive the media to be hostile toward their point of view the more they are convinced that media coverage makes their counter-party more extreme. The more they are convinced of this, the more they accept incivility but not an uncompromising rhetoric. The indirect effect of hostile media perceptions on their acceptance of incivility is significant and located far from zero, indicating a relatively strong indirect effect (acceptance of incivility: $B=1.1654 ; S E=.6577 ; 95 \%$ Confidence interval $[.3055 ; 3.3999])$. In short, among both the opponents of aircraft noise and the proponents of air traffic, hostile media perceptions relate to the presumption that coverage makes the opponents of aircraft noise more extreme. This presumption, in turn, positively relates to both sides' acceptance of incivility, and, in the case of the opponents against aircraft noise, their acceptance of an uncompromising rhetoric.

\section{Summary and Discussion}

The starting point of the present investigation was the assumption that in a mediated conflict, the antagonists will probably watch media coverage carefully, perceive that it is biased against their views and derive conclusions about how their own side and their adversaries will react to media coverage. 
From these conclusions, they will likely derive their own styles of communication in public. The present study shows that, contrary to the expectations hostile media perceptions were not directly associated with the antagonists' acceptance of an aggressive or uncompromising style of communication. But there was an indirect relationship between the antagonists' hostile media perceptions and their acceptance of an aggressive style of communication operating through the belief that the media make the opponents of aircraft noise more extreme.

The results raise at least three important questions. First, why do hostile media perceptions not relate directly to the antagonists' acceptance of incivility? Although quite a few studies have indicated the relevance of hostile media perceptions when explaining antagonists' discursive activities, none has considered antagonists' presumptions of media effects on the conflicting parties. It seems plausible that perceptions of hostile media make antagonists reason about the effects of media coverage on the development of the conflict, e.g. the strategic moves and emotional reactions of their own and their counterparty. One can assume that their presumptions of effects, in turn, determine their own behavioral, attitudinal or emotional reactions. Future research on conflicts should clarify if, and precisely what, presumptions of media effects on the conflicting parties prove to be robust mediators of the relationship between antagonists' hostile media perceptions and acceptance of incivility. 
Second, why is the relationship between hostile media perceptions and acceptance of incivility mediated by different variables in the two groups? I.e., why is it mediated by the opponents' presumptions of media effects on their in-group, and why is it mediated by the proponents' presumptions of media effects on their out-group? The opponents of aircraft noise and the proponents of air traffic are very different interest groups. The opponents form a highly coordinated social movement. Their success depends on their ability to make their case heard in public. They regularly organize demonstrations, and other public events, publish information, etc. Because of the coordinated nature of their movement one can assume that the opponents of aircraft noise act because of normative influence. It seems plausible that their presumptions that the media make their movement more extreme function as a perceived group norm to which they adapt when they accept an aggressive or uncompromising style of communication. The proponents of air traffic are a much looser group. They are strategic partners in the conflict over aircraft noise, but on other issues - such as airport fees for airlines - they are opponents. Because aircraft noise is an uncomfortable issue for them, they do not push it in public but rather evade it by communicating about the public benefits of air traffic. In the public controversy over aircraft noise, they behave reactively rather than proactively. It seems plausible that their presumptions that the media make the highly visible opponents of aircraft noise more extreme function as an indicator of the tone of the debate to which they react by accepting, or justifying a more aggressive style of communication. 
Third, why do hostile media perceptions, mediated through their presumptions of media influences, relate to the opponents' but not to the proponents' acceptance of an uncompromising rhetoric? The antagonists' acceptance of incivility was measured by asking them for their level of understanding or acceptance of an emotional aggressive reaction. By contrast, their acceptance of an uncompromising rhetoric was measured by asking them for their level of agreement with a rule, a principle or general strategy (i.e., "In a public controversy, one must express one's claims as uncompromisingly as possible."). The present study suggests that from their hostile media perceptions, mediated by their presumptions of media influence, the opponents derive an uncompromising rhetoric as a general strategy while the proponents do not. For the opponents of aircraft noise, appearing uncompromising in public seems a sensible strategy indeed to insist on their cause in a persistent way. For the proponents of air traffic, by contrast, it may not be a sensible strategy. From a strategic point of view, they might be more interested in appeasing and silencing the protesters in public than provoking them. While hostile media perceptions, mediated through their presumptions of media effects, appear to increase their understanding or justification of aggressive gut reactions in public they do not seem to influence their general communication strategy. One reason for this may be their professionalism in communication. Unlike the opponents of aircraft noise, the proponents are professionally trained communicators. In the present case, they seem to be able to choose their strategies independently of 
their perceptions of hostile media - although these perceptions increase their justification of aggressive gut reactions in public.

The results have important implications for the future study of social conflicts in media democracies. Presumptions of media effects on the negotiations between antagonists seem to be powerful mediators of the relationship between antagonists' hostile media perceptions and their styles of communication. The present correlational study suggests a specific dynamic of mediated conflicts, namely that due to hostile media perceptions and consequent presumptions of media effects on the antagonists, the tone of a controversy becomes more heated. Although many studies explaining communicative or participatory actions have made use of the concepts of hostile media perceptions and presumed media influence, no systematic study of the dynamics of conflicts has been conducted. Many efforts have been undertaken to study the psychological underpinnings of the hostile media phenomenon and third person perceptions. Rarely, however, have these concepts been used to build social scientific theories of the dynamics of mediated conflicts.

The present study is a first step to develop such a theory. From it, a few conclusions can be drawn for future studies. Hostile media perceptions as well as presumptions of media effects on the two sides in a conflict seem to be relevant parts of such a theory. The results suggest that due to hostile media perceptions, the antagonists perceive a polarization of the conflict and, as a consequence, become more aggressive and possibly more uncompromising. This 
suggests a spiral of polarization on both sides of the conflict, leading to irreconcilable claims and positions. However, there are many more possible presumptions of media effects that could be relevant in such a theory. They should be identified in future studies. What is more, in order to develop and test a theory of the dynamics of conflicts in media democracies and to establish causal relationships, longitudinal studies are necessary to capture media coverage, perceptions of media content, presumptions of media effects and communicative intentions or behaviors over time. Collecting data on several specific conflicts, relevant parameters of the antagonizing groups could be controlled for such as their visibility in public, their level of organization, their network qualities, resources and other important features.

Making only a first step to develop a theory of social conflicts in media democracies, this study has limitations. First, it is a correlational study making causal conclusions problematic. However, as past research has indicated, hostile media perceptions seem to explain presumptions of media effects better than vice versa. Nevertheless, if these assumptions hold must be tested in future studies.

Second, the samples in this study are rather small, particularly of the supporters of air traffic. Due to the small numbers of participants - i.e. 82 opponents of aircraft noise and 48 proponents of air traffic - important effects may have been overlooked. Other effects are just about significant and it is hard to tell how robust they are. With about 150 subjects on each side of the conflict the 
populations are rather small, too. This points at a general problem in the study of public communication in conflicts. Though in many mediated conflicts, there are a large number of partisan bystanders on each side of the conflict, there are usually only small populations of antagonists officially speaking up in public, making it difficult to conduct quantitative surveys.

What is more, there is reason to assume that the final sample of respondents is biased. In general, one can expect that the most involved are the most eager to participate. However, in the case of the opponents of aircraft noise from the Frankfurt area where the conflict is most heated and where turnout was lowest, the most involved may have been the most reluctant to participate. Those who refused may systematically differ from the participants in that they are more suspicious of their opponents, of scientific studies, and, maybe also of the media - raising the question if their refusals might have influenced the results. For instance, the relationships between hostile media perceptions, presumed media influences and acceptance of an uncivil or uncompromising style of communication may have been more pronounced if the suspicious had participated in the survey. This is only an assumption, however, that cannot be tested based on the present data. Another source of potential bias is nonresponse. More than 20 percent of the participants were excluded from the models due to their refusals to answer particular questions. Mean comparisons revealed no great systematic differences between respondents and non-respondents. However, it cannot be ruled out, for instance, that there are associational differ- 
ences between them, which is why the results of the present study should be generalized with caution.

Third, the present study considers the ratings of the speakers of the citizen action groups and organizations. Thus, the results cannot be applied to the many people engaged in discursive activities on their own behalf - e.g. by carrying banners in demonstrations, writing letters to newspaper editors, posting messages in blogs or social media. The present study relied on those officially representing citizen action groups in public and in politics - those, in other words, who are most likely to shape the public debate displayed in the media. Yet because a great deal of the communication in conflicts takes place in demonstrations and online media, future studies should take this kind of participation into account and check if users' or protesters' perceptions of media coverage and inclinations toward incivility differ from those of the official speakers. It could well be that the anger displayed on unofficial sites, e.g. in protests or social media, share their part in heating up a controversy.

What is more, the present study is a case study and thus difficult to generalize. The mechanisms suggested may be applicable to conflicts over similar issues and with a similar structural setting. The conflict over aircraft noise is a conflict between a social movement of citizens directly affected by aircraft noise and a well-established group of lobbyists with vivid and stable connections to politicians. It seems plausible that similar conflicts - e.g. conflicts over public building projects, or over the use of nuclear power or fracking in particular 
regions - contain similar relationships between hostile media perceptions, presumptions of media influences on the demonstrating parties, and the antagonists' acceptance of incivility. Other conflicts may contain different relationships. For instance, it seems plausible that in conflicts between equally established parties - e.g. in conflicts over moral issues such as abortion or embryo screening - presumptions of media effects on both sides of the conflict play an important role. While quite a few studies have already pointed at the relevance of hostile media perceptions and presumptions of media effects, future studies should investigate just how the relationships and relevant presumptions of media effects vary with different conflict settings and types of issues.

Fourth, this study measured hostile media perceptions by asking respondents to rate media coverage of air traffic in general instead of asking them to rate specific media contents. Doing so, it used the same approach as many previous survey studies on the consequences of hostile media perceptions (Barnidge \& Rojas 2014, 143; Feldman et al. 2015, 10; Hwang et al. 2008, 82; Rojas 2010, 354; Tsfati 2007, 639). One may wonder, however, if such ratings are valid measures of hostile media perceptions. The hostile media phenomenon is about partisans perceiving identical news contents as biased against their views. In the present study as well as in the studies cited, we strictly do not know if people rate identical sets of media contents and if, therefore, hostile media perceptions are present. While it seems plausible that the antagonists in conflicts have a close eye on mainstream media coverage (cf. Kep- 
plinger 2007) and therefore base their ratings on more or less similar sets of media contents future research should investigate if this is a valid assumption.

Fifth, previous research has identified various forms of incivility (e.g. Coe, Kenski \& Rains 2014, 661; Sobieraj \& Berry 2011), such as aspersion ("mean-spirited words directed at an idea"), lying ("stating or implying that an idea, plan, or policy was disingenuous"), vulgarity (“Using (...) language that would not be considered proper (...) in professional discourse") or pejorative for speech ("disparaging remarks about the way in which a person communicates"). In order not to overload the questionnaires, this study focused on one form of incivility - "name calling", i.e. "mean-spirited or disparaging words directed at a person or group of people" (Coe et al. 2014). Future research should clarify if hostile media perceptions and presumptions of the media polarizing the antagonists in a controversial debate also relate with forms of incivility other than name-calling.

Despite its limitations, the present study has some implications for the way conflicts are fought and arguments are exchanged in modern democracies. One important function of the mass media has been seen in their capability to provide the citizens with a balanced selection of a society's most important issues and arguments - i.e. a common ground constituting a society's political reality (Bennet \& Iyengar 2008). It seems, however, that the antagonists in conflicts do not acknowledge the media as neutral or fair mediators but perceive them as partisan players acting against them. One of the consequences 
suggested by this study is an increasing degree of polarization between the antagonists leading to an increasingly aggressive tone. This process could be aggravated in digitalized media landscapes where citizens can select channels of communication exposing them to reaffirming while shielding them from countering arguments (Feldman, Myers, Hmielowski \& Leiserowitz 2014). It seems plausible that a high level of general distrust toward the mass media further aggravates polarization resulting from hostile media perceptions and presumed media influences. Future studies should investigate if general trust in the mass media can alleviate such processes. What is more, the media have been found to be very ready to report instances of conflict and incivility (Sobieraj \& Berry 2011). Their selection of angry and aggressive sources may play their part in heating up conflicts. One possible longterm effect of incivility in the media and among partisan antagonists might be an erosion of trust both in the media and in democracy.

\footnotetext{
${ }^{\mathrm{i}}$ The model explaining their acceptance of incivility is only marginally significant at the .1level. Because of the small sample size, it will be fully described in the following. ${ }^{\mathrm{ii}}$ Forthefollowingmeancomparisons, therearenosignificantdifferences at the .05, or .1-level (Ttest): Opponentsofaircraftnoise: hostilemediaperceptions:respondents: $\bar{x}=5.17, \mathrm{SD}=1.25$, non-respondents: $\bar{x}=5.48, \mathrm{SD}=1.21$; presumed media influence on own party:respondents: $\bar{x}$ $=4.63, \mathrm{SD}=1.08$, non-respondents: $\bar{x}=4.83, \mathrm{SD}=1.38$; presumed media influence on counter-party: respondents: $\bar{x}=4.80, \mathrm{SD}=1.45$, non-respondents: $\bar{x}=4.96, \mathrm{SD}=1.26$; acceptance of incivility: respondents: $\bar{x}=28.85, \mathrm{SD}=9.98$, non-respondents: $\bar{x}=26.38, \mathrm{SD}=10.58$; acceptance of uncompromising rhetoric:respondents: $\bar{x}=5.05, \mathrm{SD}=1.54$, non-respondents: $\bar{x}=$ 4.74, $\mathrm{SD}=2.01$; own stance on the issue: respondents: $\bar{x}=1.95, \mathrm{SD}=1.11$, non-respondents: $\bar{x}=1.95, \mathrm{SD}=1.18$; perceived politicians' stance on the issue: respondents: $\bar{x}=5.61, \mathrm{SD}=$ .910 , non-respondents: $\bar{x}=5.48, \mathrm{SD}=1.53$; media self-efficacy: respondents: $\bar{x}=3.76, \mathrm{SD}=$ 1.85 , non-respondents: $\bar{x}=4.09, \mathrm{SD}=1.48$; media use: respondents: $\bar{x}=19.5, \mathrm{SD}=5.72$, nonrespondents: $\bar{x}=21.0, \mathrm{SD}=5.77$.
} 
Proponents of air traffic: hostilemediaperceptions:respondents: $\bar{x}=5.54, \mathrm{SD}=.960$, nonrespondents: $\bar{x}=5.73, \mathrm{SD}=1.01$; presumed media influence on own party:respondents: $\bar{x}=$ $3.78, \mathrm{SD}=.976$, non-respondents: $\bar{x}=3.50, \mathrm{SD}=1.23$; presumed media influence on counterparty: respondents: $\bar{x}=5.27, \mathrm{SD}=1.15$, non-respondents: $\bar{x}=6.00, \mathrm{SD}=1.25$; acceptance of incivility: respondents: $\bar{x}=17.03, \mathrm{SD}=6.68$, non-respondents: $\bar{x}=15.00, \mathrm{SD}=7.57$; own stance on the issue: respondents: $\bar{x}=5.19, \mathrm{SD}=.908$, non-respondents: $\bar{x}=5.25, \mathrm{SD}=1.04$; perceived politicians' stance on the issue: respondents: $\bar{x}=3.97, \mathrm{SD}=1.07$, non-respondents: $\bar{x}=4.00, \mathrm{SD}=1.33$; media self-efficacy: respondents: $\bar{x}=4.00, \mathrm{SD}=1.25$, non-respondents: $\bar{x}$ $=3.70, \mathrm{SD}=2.00$; media use: respondents: $\bar{x}=21.0, \mathrm{SD}=5.53$, non-respondents: $\bar{x}=17.9$, $\mathrm{SD}=7.96$ 


\section{References}

Altheide, D., \& Snow, R. P. (1979). Media logic. Beverly Hills, CA: Sage.

Amann, M., Dohle, M., Rass, S. (2012): Wahrgenommene Medieneinflüsse und ihre Bedeutung für Kommunikationsaktivitäten von Lokalpolitikern [Perceived Media Influences and their Relevance for the Communication Activities of Local Politicians]. Studies in Communication / Media, 1 (3-4), 493-505.

Barndige, M. \& Rojas, H. (2014). Hostile media perceptions, presumed media influence, and political talk: Expanding the corrective action hypothesis. International Journal of Public Opinion Research, 26(2), 135-156. doi: 10.1093/ijpor/edt032.

Bennett, W. L., \& Iyengar, S. (2008). A new era of minimal effects? The changing foundations of political communication. Journal of Communication, 58(4), 707-731.

Bernhard, U. \& Dohle, M. (2013). Indirekte Medienwirkungen bei der Volksabstimmung über "Stuttgart 21". Wahrgenommene Medieneinflüsse und ihre Konsequenzen [Indirect Media Effects in the Context of the Plebiscite on Stuttgart 21: Perceived Media Influences and their Consequences]. Medien \& Kommunikationswissenschaft, 61(1), 38-57.

Bernhard, U. \& Dohle, Marco (2014): Do Even Journalists Support Media Restrictions? Presumed Political Media Influences and the Conse- 
quences. Journalism \& Mass Communication Quarterly, 91 (2), 250271.

Bernhard, U. \& Dohle, M. (2015a): Local Politics Online: The Influence of Presumed Influence on Local Politicians' Online Communication Activities in Germany. Advance online publication. Local Government Studies, 1-19.

Berhard, U. \& Dohle, M. (2015b): Corrective or Confirmative Actions? Political Online Participation as a Consequence of Presumed Media Influences in Election Campaigns. Advance online publication. Journal of Information Technology \& Politics, 1-53.

Chia, S. C. (2006): How Peers Mediate Media Influence on Adolescents' Sexual Attitudes and Sexual Behavior. Journal of Communication 56 (2006), 585-606.

Chois, J., Yang, M. \& Chang, J. C. (2009). Elaboration of the hostile media phenomenon: The roles of involvement, media skepticism, congruency of perceived media influence, and perceived opinion climate. Communication Research, 36(1), 54-75. doi: 10.1177/0093650208326462.

Coe, K., Tewksbury, D., Bond, B. J., Drogos, K. L., Porter, R. W., Yahn, A. \& Zhang, Y. (2008). Hostile news: Partisan use and perceptions of cable news programming. Journal of Communication, 58(2), 201-219. doi: 10.1111/j.1460-2466.2008.00381.x. 
Coe, K., Kenski, K., \& Rains, S. A. (2014). Online and uncivil? Patterns and determinants of incivility in newspaper website comments. Journal of Communication, 64(4), 658-679.

Cohen, J., Tsfati, Y., and Sheafer, T. (2008). The influence of presumed media influence in politics: Do politicians' perceptions of media power matter? Public Opinion Quarterly, 72(2), 331-344. doi: $10.1093 / \mathrm{poq} / \mathrm{nfn} 014$.

Cohen, J., Weimann, G. (2008): Who's Afraid of Reality Shows? Exploring the Effects of Perceived Influence of Reality Shows and the Concern Over Their Social Effects on Willingness to Censor. Communication Research, 35 (3), 382-397.

Cohen, J. \& Tsfati, Y. (2009): The Influence of Presumed Media Influence on Strategic Voting. Communication Research, 36 (3), 359-378.359-378.

Davison, W. P. (1983). The third-person effect in communication. Public Opinion Quarterly, 47(1), 1-15. doi: 10.1086/268763

De Nooy, W. \& Kleinnijnhuis, J. (2013). Polarization in the media during an election campaign: A dynamic network model predicting support and attack among political actors. Political Communication, 30(1), 117138. doi: $10.1080 / 10584609.2012 .737417$.

Deutsche Flugsicherung [DFS, German flight control] (2013). Luftverkehr in Deutschland. Mobilitätsbericht 2012 [Air traffic in Germany. Mobility $\begin{array}{lll}\text { report 2012]. } & \text { Retrieved }\end{array}$ 
http://www.dfs.de/dfs_homepage/en/Press/Publications/Mobilitaetsberich t_2012_Web.pdf.

Deutsches Institut für Public Affairs (2006). Verbandslobbying und Verbandsmanagement: Einfluss und Erfolgsfaktoren in Berlin und Brüssel [Interest Groups' Lobbying and Managing Interest Groups: Influence and Factors of Success]. Minster: LIT.

Eveland, W. P., Morey, A. C., Hutchens, M. J. (2011): Beyond deliberation: New directions for the study of informal political conversation from a communication perspective. Journal of Communication, 61(6), 10821103. doi: 10.1111/j.1460-2466.2011.01598.x

Feldman, L., Myers, T. A., Hmielowski, J. D., \& Leiserowitz, A. (2014). The Mutual Reinforcement of Media Selectivity and Effects: Testing the Reinforcing Spirals Framework in the Context of Global Warming. Journal of Communication, 64(4), 590-611.

Feldman, L., Hart, P. S., Leiserowitz, A., Maibach, E. \& Roser-Renouf, C. (2015): Do Hostile Media Perceptions Lead to Action? The Role of Hostile Media Perceptions, Political Efficacy, and Ideology in Predicting Climate Change Activism. Advance Online Publication. Communication Research.

Field, A. (2013). Discovering Statistics Using IBM SPSS Statistics. Los Angelos, CA.: Sage. 
Gunther, A. C. \& Storey, D. J. (2003). The Influence of Presumed Influence, Journal of Communication, 53(2), 199-215. Doi: 10.1111/j.14602466.2003.tb025.

Gunther, A. C., Bolt, D., Borzekowski, D. L., Liebhart, J. L., \& Dillard, J. P. (2006). Presumed influence on peer norms: How mass media indirectly affect adolescent smoking. Journal of Communication, 56(1), 52-68.

Gunther, A. C. 2008. Hostile media phenomenon. In W. Donsbach (Ed.), The international encyclopedia of communication, Vol. 5, (pp.2139-2143). Malden, MA: Blackwell. doi: 10.1111/b.9781405131995.2008.x

Hartman, T. \& Tanis, M. (2013). Examining the hostile media effect as an intergroup phenomenon: The role of ingroup identification and status. Journal of Communication, 63(3), 535-555. doi: 10.1111/jcom.12031.

Hayes, A. F. (2013). Introduction to Mediation, Moderation, and Conditional Process Analysis: A Regression-Based Approach. New York: Guilford Press.

Hmielowski, J. D., Hutchens, M. J. \& Cicchirillo, V. J. (2014). Living in an age of online incivility: examining the conditional indirect effects of online discussion on political flaming. Information, Communication \& Society, 17(10), 1196-1211. doi: 10.1080/1369118X.2014.899609.

Ho, S. S., Binder, A. R., Becker, A. B., Moy, P., Scheufele, D. A., Brossard, D., et al. (2011). The role of perceptions of media bias in general and issue-specific participation. Mass Communication and Society, 14(3), 343-374. doi: 10.1080/15205436.2010.491933. 
Hoffner, C. \& Rehkoff, R. A. (2011): Young Voters' Responses to the 2004 U.S. Presidential Election: Social Identity, Perceived Media Influence, and Behavioral Outcomes. Journal of Communication, 61 (2011), 732757.

Huge, M. \& Glynn, C. J. (2010). Hostile media and the campaign trail: Perceived media bias in the race for governor. Journal of Communication, 60(1), 165-181. Doi: 10.1111/j.1460-2466.2009.01473.x.

Hwang, H., Z. Pan, and Y. Sun. 2008. Influence of hostile media perception on willingness to engage in discursive activities: An examination of mediating role of media indignation. Media Psychology, 11(1): 76-97. doi: 10.1080/15213260701813454.

Kepplinger H. M. (2009). Publizistische Konflikte und Skandale [Mediated Conflicts and Scandals]. Wiesbaden, Germany: VS Verlag.

Kepplinger, H. M. (2007). Towards a theory of mass media effects on decision makers. The Harvard International Journal of Press/Politics, 12(2), 323. doi: $10.1177 / 1081180 X 07299798$.

Kepplinger, H.M. (2008). Reciprocal effects. In W. Donsbach (Ed.), The International Encyclopedia of Communication (pp. 4143-4147). Oxford: Blackwell Publishing Ltd. doi: 10.1111/b.9781405131995.2008.x.

Lang, K. \& Lang, G. E. (1952). The Unique Perspective of Television and its Effects: A Pilot Study. American Sociological Review, 18(1),3-12.

Matthes, J. (2013). The affective underpinnings of hostile media perceptions: Exploring the distinct effects of affective and cognitive involvement. 
Communication $\quad$ Research, 40(3), 360-387. doi: $10.1177 / 0093650211420255$.

Oliver, M. B., Yang, H., Ramasubramanian, S., Kim, J., Lee, S. (2008): Exploring Implications of Perceived Media Reinforcement on ThirdPerson Perceptions. Communication Research, 35 (6), 745-769.

Paek, H.-J. (2009): Differential Effects of Different Peers: Further Evidence of the Peer Proximity Thesis in Perceived Peer Influence on College Students' Smoking. Journal of Communication, 59 (2009), 434-455.

Perloff, R. M. (1999). The third-person effect: A critical review and synthesis. Media Psychology, 1(4), 353-378. doi:10.1207/s1532785xmep0104 4.

Preacher, K. J. \& Hayes, A. F. (2008). Asymptotic and resampling strategies for assessing and comparing indirect effects in multiple mediator models. Behavior Research Methods, 40(3), 879-891. doi: 10.3758/BRM.40.3.879.

Reid, S.A. (2012). A self-categorization explanation for the hostile media effect. Journal of Communication, 62(3), 381-399. doi:10.1111/j.1460$\underline{2466.2012 .01647 . x}$

Rojas, H. (2010). "Corrective" actions in the public sphere: How perceptions of media and media effects shape political behaviors. International Journal of Public Opinion Research, 22(3), 343-363. doi: 10.1093/ijpor/edq018. 
Sobieraj, S., \& Berry, J. M. (2011). From incivility to outrage: Political discourse in blogs, talk radio, and cable news. Political Communication, $28(1), 19-41$.

Strömbäck, J. (2008). Four phases of mediatization: An analysis of the mediatization of politics. International Journal of Press / Politics 13(3), 228246. doi: $10.1177 / 1940161208319097$.

Stroud, N. J., Muddiman, A. \& Lee, J. K. (2014). Seeing media as group members: An evaluation of partisan bias perception. Journal of Communication, 64(5), 874-894. DOI: 10.1111/jcom.12110.

Tal Or, N., Tsfati, Y., \& Gunther, A. C. (2009). The influence of presumed media influence: Origins and implications of the third-person perception. In R. Nabi \& M. B. Oliver (Eds), The Sage Handbook of Media Processes and Effects (pp. 99-112). Thousand Oaks, CA: Sage.

Tsfati, Y. \& Cohen, J. (2005). The influence of presumed media influence on democratic legitimacy: The case of Gaza settlers. Communication Research, 32(6), 794-821. doi: 10.1177/0093650205281057.

Tsfati, Y. (2007). Hostile media perceptions, presumed media influence and minority alienation: The case of Arabs in Israel. Journal of Communication, 57(4), 632-651. Doi: 10.1111/j.1460-2466.2007.00361.x

Tsfati, Y., Cohen, J. \& Gunther, A. C. (2011). The influence of presumed media influence on news about science and scientists. Science Communication, 33(2), 143-166. doi: 10.1177/1075547010380385. 
Vallone, R.P., Ross, L., \& Lepper, M.R. (1985). The hostile media phenomenon: Biased perception and perceptions of media bias in coverage of the Beirut massacre. Journal of Personality and Social Psychology, 49(3), 577-85. Doi: 10.1037/0022-3514.49.3.577.

Wolf, M. R., Strachan, C. \& Shea, D. M. (2012). Forget the good of the game: political incivility and lack of compromise as a second layer of party polarization. American Behavioral Scientist, 56(12), 1677-1695. doi: $10.1177 / 0002764212463355$ 
Figure 1. Mediated effects model: Direct and indirect effects of hostile media perceptions on acceptance of incivility and acceptance of an uncompromising rhetoric

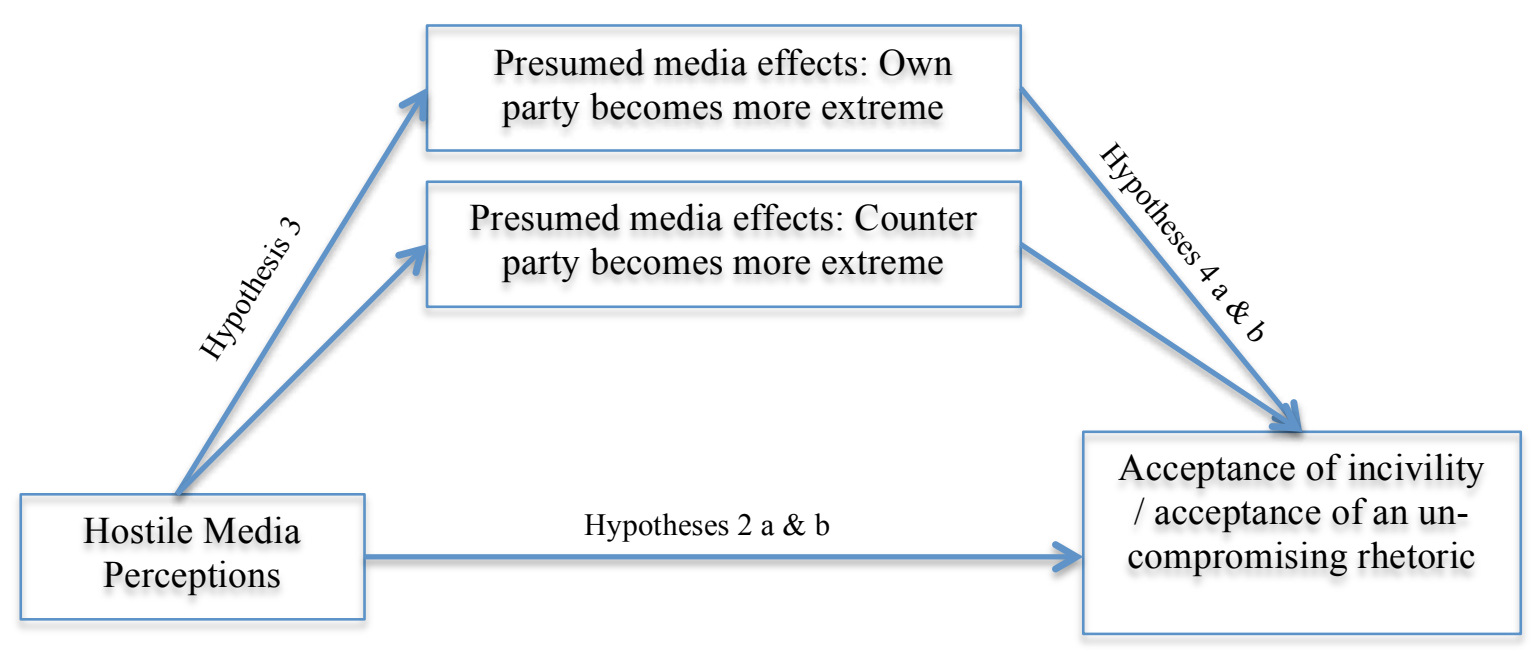


Table 1: Distribution of citizen action groups in the population of German action groups and among participants

\begin{tabular}{|c|c|c|}
\hline & $\begin{array}{c}\text { Population } \\
(\mathrm{n}=175) \\
\%\end{array}$ & $\begin{array}{c}\text { Participants } \\
\qquad(\mathrm{n}=82) \\
\%\end{array}$ \\
\hline Frankfurt & 34 & 17 \\
\hline Munich & 26 & 31 \\
\hline Cologne / Bonn & 11 & 11 \\
\hline Berlin & 7 & 9 \\
\hline Halle / Leipzig & 3 & 4 \\
\hline $\begin{array}{l}\text { remaining (e.g. Hannover, Dresden, Hamburg, } \\
\text { Memmingen) }\end{array}$ & 19 & 29 \\
\hline Total & 100 & 101 \\
\hline
\end{tabular}


Table 2: Influence of presumed media influence and perceived media hostility on acceptance of incivility and on acceptance of an uncompromising rhetoric

- Unstandardized Regression Weights (B) and standard errors (SE) -

\begin{tabular}{|c|c|c|c|c|}
\hline & \multicolumn{2}{|c|}{ Opponents of aircraft noise } & \multicolumn{2}{|c|}{ Proponents of air traffic } \\
\hline & $\begin{array}{l}\text { Acceptance of inci- } \\
\text { vility }\end{array}$ & $\begin{array}{l}\text { Acceptance of un- } \\
\text { com-promising rhet- } \\
\text { oric }\end{array}$ & $\begin{array}{l}\text { Acceptance of inci- } \\
\text { vility }\end{array}$ & $\begin{array}{l}\text { Acceptance of un- } \\
\text { com-promising rhet- } \\
\text { oric }\end{array}$ \\
\hline & $\mathrm{B}(\mathrm{SE})$ & $\mathrm{B}(\mathrm{SE})$ & $\mathrm{B}(\mathrm{SE})$ & $\mathrm{B}(\mathrm{SE})$ \\
\hline Constant & $9.245(9.173)$ & $2.453(1.516)$ & $-3.693(11.825)$ & $3.004(2.851)$ \\
\hline \multicolumn{5}{|l|}{ Main Variables } \\
\hline $\begin{array}{l}\text { Perceived media hostility: friendly media (1) / hostile } \\
\text { media ( } 7 \text { ) }\end{array}$ & $.275(1.040)$ & $-.249(.171)$ & $1.168(1.202)$ & $.287(.288)$ \\
\hline $\begin{array}{l}\text { Perceived media influence on own party - our party's } \\
\text { claims become more moderate (1) / extreme ( } 7)\end{array}$ & $2.894 *(1.185)$ & $.486 *(.196)$ & $-.1 .239(1.085)$ & $.197(.262)$ \\
\hline $\begin{array}{l}\text { Perceived media influence on counterparty - their par- } \\
\text { ty's claims become more moderate }(1) \text { / extreme }(7)\end{array}$ & $.533(.948)$ & $-.195(.157)$ & $2.870 *(1.070)$ & $-.257(.254)$ \\
\hline \multicolumn{5}{|l|}{ Covariates } \\
\hline $\begin{array}{l}\text { Media self-efficacy: own party's standpoint is listened } \\
\text { to by the media: do not agree (1) / agree (/) }\end{array}$ & $-.913(.676)$ & $.098(.110)$ & $-.560(.839)$ & $.239(.203)$ \\
\hline $\begin{array}{l}\text { Individual standpoints on the future development of air } \\
\text { traffic: should be reduced (1) / expanded ( } 7)\end{array}$ & $-3.361 *(1.078)$ & $-.273(.177)$ & $.202(1.199)$ & $.065(.290)$ \\
\hline $\begin{array}{l}\text { Estimation of politicians' standpoint on the future de- } \\
\text { velopment of air traffic: should be reduced (1) / ex- } \\
\text { panded ( } 7 \text { ) }\end{array}$ & $1.100(1.426)$ & $.516 *(.235)$ & $.866(1.089)$ & $-.358(.264)$ \\
\hline Media use & $.310(.214)$ & $-.007(.034)$ & $.074(.191)$ & $-.024(.046)$ \\
\hline \multirow[t]{2}{*}{ Model summary } & $\mathrm{R}^{2}=.367$ & $\mathrm{R}^{2}=.241$ & $\mathrm{R}^{2}=.348$ & $\mathrm{R}^{2}=.124$ \\
\hline & $\mathrm{p}<.05$ & $\mathrm{p}<.05$ & $\mathrm{p}=.063$ & n.s. \\
\hline
\end{tabular}

Note: The number of cases was reduced due to missing data. The model explaining opponents' acceptance of incivility excluded 23 out of 82 cases, the model explaining opponents' acceptance of an uncompromising rhetoric excluded 21 out of 82 cases. The model explaning proponents' acceptance of incivility excluded 11 out of 48 cases, the model explaining proponents' acceptance of an uncompromising rhetoric excluded 10 out of 48 cases.

Significant effects are printed in bold $\left(* \mathrm{p}<.05,{ }^{+} \mathrm{p}<.1\right)$. 
Table 3: Influence of perceived media hostility on perceived media influence on own party and counterparty

- Unstandardized Regression Weights (B) and standard errors (SE) -

\begin{tabular}{|c|c|c|c|c|c|}
\hline & \multicolumn{2}{|c|}{ Opponents of aircraft noise } & \multicolumn{3}{|c|}{ Proponents of air traffic } \\
\hline & $\begin{array}{l}\text { Media make own party } \\
\text { more extreme }\end{array}$ & $\begin{array}{l}\text { Media make counter- } \\
\text { party more extreme }\end{array}$ & $\begin{array}{l}\text { Media make own party } \\
\text { more extreme }\end{array}$ & & $\begin{array}{l}\text { Media make counter- } \\
\text { party more extreme }\end{array}$ \\
\hline & $\mathrm{B}(\mathrm{SE})$ & $\mathrm{B}(\mathrm{SE})$ & $\mathrm{B}(\mathrm{SE})$ & & $\mathrm{B}(\mathrm{SE})$ \\
\hline Constant & $1.484(1.074)$ & $.395(1.343)$ & $4.765(1.571)$ & & $4.632(1.592)$ \\
\hline \multicolumn{6}{|l|}{ Main variables } \\
\hline $\begin{array}{l}\text { Perceived media hostility: friendly media (1) / hostile } \\
\text { media ( } 7 \text { ) }\end{array}$ & $.287 *(.114)$ & $.346 *(.142)$ & $-.245 .(.180)$ & & $.406 *(.182)$ \\
\hline $\begin{array}{l}\text { Perceived media influence on own party - our party's } \\
\text { claims become more moderate (1) / extreme ( } 7)\end{array}$ & - & - & - & - & - \\
\hline $\begin{array}{l}\text { Perceived media influence on counterparty - their par- } \\
\text { ty's claims become more moderate }(1) \text { / extreme }(7)\end{array}$ & - & - & - & - & - \\
\hline \multicolumn{6}{|l|}{ Covariates } \\
\hline $\begin{array}{l}\text { Media self-efficacy: own party's standpoint is listened } \\
\text { to by the media: do not agree (1) / agree (/) }\end{array}$ & $.106(.079)$ & $.014(.099)$ & $-.019(.136)$ & & $.167(.138)$ \\
\hline $\begin{array}{l}\text { Individual standpoint on the future development of air } \\
\text { traffic: should be reduced (1) / expanded (7) }\end{array}$ & $-.022(.124)$ & $-.286^{+}(.156)$ & $.047(.194)$ & & $-.229(.197)$ \\
\hline $\begin{array}{l}\text { Estimation of politicians'standpoint on the future de- } \\
\text { velopment of air traffic: should be reduced (1)/ ex- } \\
\text { panded ( } 7)\end{array}$ & $.339 *(.152)$ & $.639 *(.190)$ & $-.148(.165)$ & & $-.391 *(.167)$ \\
\hline Media use & $-.031(.025)$ & $-.024(.031)$ & $.038(.031)$ & & $.022(.031)$ \\
\hline \multirow[t]{2}{*}{ Model summary } & $\mathrm{R}^{2}=.205$ & $\mathrm{R}^{2}=.306$ & $\mathrm{R}^{2}=.103$ & & $\mathrm{R}^{2}=.332$ \\
\hline & $\mathrm{p}<.05$ & $\mathrm{p}<.05$ & n.s. & & $\mathrm{p}<.05$ \\
\hline
\end{tabular}

Note: The number of cases was reduced due to missing data. The model explaining opponents' presumptions of media effects excluded 23 out of 82 cases.

The model explaning proponents' presumptions of media effects excluded 11 out of 48 cases.

Significant effects are printed in bold $\left(* \mathrm{p}<.05,{ }^{+} \mathrm{p}<.1\right)$ 